Article

\title{
Combined Mining and Pulp-Lifting of Ferromanganese Nodules and Rare-Earth Element-Rich Mud around Minamitorishima Island in the Western North Pacific: A Prefeasibility Study
}

\author{
Tetsuo Yamazaki ${ }^{1, *(D)}$, Naoki Nakatani ${ }^{1}$, Rei Arai ${ }^{1}$, Tsunehiro Sekimoto ${ }^{2}$ and Hiroyuki Katayama ${ }^{2}$ \\ 1 Graduate School of Engineering, Osaka Prefecture University, 1-1 Gakuen-cho, Naka-ku, Sakai, \\ Osaka 599-8531, Japan; nakatani@marine.osakafu-u.ac.jp (N.N.); arai@marine.osakafu-u.ac.jp (R.A.) \\ 2 Penta-Ocean Construction Co., Ltd., 1534-1 Yonku-cho, Nasushiobara, Tochigi 329-2746, Japan; \\ tsunehiro.sekimoto@mail.penta-ocean.co.jp (T.S.); hiroyuki.katayama@mail.penta-ocean.co.jp (H.K.) \\ * Correspondence: yamazaki@marine.osakafu-u.ac.jp; Tel.: +81-72-254-8523
}

Citation: Yamazaki, T.; Nakatani, N.; Arai, R.; Sekimoto, T.; Katayama, H. Combined Mining and Pulp-Lifting of Ferromanganese Nodules and Rare-Earth Element-Rich Mud around Minamitorishima Island in the Western North Pacific: A Prefeasibility Study. Minerals 2021, 11, 310. https://doi.org/10.3390/ $\min 11030310$

Academic Editor: Shiki Machida and Kentaro Nakamura

Received: 20 January 2021

Accepted: 14 March 2021

Published: 17 March 2021

Publisher's Note: MDPI stays neutral with regard to jurisdictional claims in published maps and institutional affiliations.

Copyright: (c) 2021 by the authors. Licensee MDPI, Basel, Switzerland. This article is an open access article distributed under the terms and conditions of the Creative Commons Attribution (CC BY) license (https:/ / creativecommons.org/licenses/by/ $4.0 /)$.

\begin{abstract}
An examination of the technical and economic feasibility of the combined mining of the rareearth element-rich mud (REE-rich mud) and ferromanganese nodules (FN) around Minamitorishima (Marcus) Island in Northwest Pacific is introduced. A previous study showed that the mining of REE-rich mud around Minamitorishima Island was not economically feasible. Therefore, in this study, three changes from the previous mining model to improve its economy are proposed. The first one is combined mining with FN in the area. The second one is introducing a pulp-lifting system that can lift both REE-rich mud and FN at high concentrations through a riser pipe. The third one is the reuse of waste mud and processed slag for construction materials. The economic evaluation results show a change from a slightly negative to quite positive economy depending on the mixing ratio of REE-rich mud and $\mathrm{FN}$ in the pulp-lifting. In addition, some technical approaches necessary to realize the combined mining method are introduced.
\end{abstract}

Keywords: deep-sea mining; pulp-lifting; ferromanganese nodule; rare-earth element-rich mud; western North Pacific

\section{Introduction}

The presence of deep-sea rare-earth element-rich mud (REE-rich mud) in the Pacific seafloor which involves high contents of rare-earth elements was reported in a previous study [1]. Two areas with high contents of REE-rich mud in the range of 500-1500 ppm, such as off Hawaii in the northeastern equatorial Pacific and off Tahiti in the southeastern Pacific, were pointed out. The authors of the paper also suggested the areas' potential as locations of rare-earth element resources. Several feasibility studies were conducted on the mining of these elements [2-4]. However, because of the presence of an overlaid sediment layer that is several tens of meters thick with poor rare-earth element contents of less than 500 ppm, the results showed that the mud's 500-1500 ppm potential was not great enough for the mining to be economical. One paper [2] proposed an in situ chemical concentration for improving the economy. In 2013, another higher content area was found by the Japan Agency for Marine-Earth Science and Technology (JAMSTEC) near Minamitorishima (Marcus) Island in the Japanese exclusive economic zone (EEZ) [5]. In this area, there are rare-earth element-rich layers with 5000-6500 ppm contents within $10 \mathrm{~m}$ below the seafloor, which is $5600-5800 \mathrm{~m}$ deep. The distribution aspects of this area and its potential as a rare-earth element resource have been reported in detail [6,7]. The feasibility of mining REE-rich mud in the area using ferromanganese nodule (FN) mining technologies was examined by Yamazaki et al. [8]. The results showed a negative economy. In this study, FN mining technologies, including feasibility studies and metallurgy, were 
reviewed as the basis of the combined mining of REE-rich mud and FN, and the mining model and the results of the economic evaluation are presented.

\section{FN and Research and Development Approaches to Mining}

Many scientific, technical, and economical publications are available on FN, mostly because they are considered the primary commercial target in deep-sea mineral resources $[9,10]$. The geological distribution characteristics have been studied in detail by numerous researchers [11-14]. However, very little detailed information on the first mining target areas in the Clarion-Clipperton Fracture Zone (CCZ) was available even in the 1990s [15,16], though the international consortium had authorized their sites in US domestic law [17] and the Pioneer Investors with the International Seabed Authority (ISA) were placed there as contractors [18]. Without enough information, basic geological and geophysical factors had to be assumed in some previous economic feasibility studies on the development [19-21]. An economic feasibility study on cobalt-rich FN inside the Cook Islands EEZ [22] stood out, because the high cobalt content in FN and a mechanical lift were assumed in the mining model. The results of these four feasibility studies are summarized and compared in Table 1. Because the market demand for manganese in the 1980s and 1990s was only $40 \%$ of that in 2019 [23], the manganese recovery from FN mining was not considered in some economic analyses [20,22]. The price reduction in the market due to the large amount of manganese supplied by FN mining was thought not to recover the additional metallurgical processing cost. 
Table 1. Summarization and comparison of earlier economic feasibility studies for ferromanganese nodule (FN) mining [19-22].

\begin{tabular}{|c|c|c|c|c|c|c|c|c|c|c|c|c|}
\hline \multirow{2}{*}{$\begin{array}{c}\begin{array}{c}\text { Authors } \\
\text { Processing method }\end{array} \\
\begin{array}{l}\text { Subsystem } \\
\text { (condition) }\end{array} \\
\end{array}$} & \multicolumn{3}{|c|}{$\begin{array}{c}\text { Andrews et al. [19] } \\
\text { Reduction and Hydrochloric } \\
\text { Acid Leach Process }\end{array}$} & \multicolumn{3}{|c|}{$\begin{array}{l}\text { Hillman and Gosling [20] } \\
\text { Cuprion Ammoniacal } \\
\text { Leach Process }\end{array}$} & \multicolumn{3}{|c|}{$\begin{array}{c}\text { Charles et al. [21] } \\
\text { Reduction and Hydrochloric } \\
\text { Acid Leach Process }\end{array}$} & \multicolumn{3}{|c|}{$\begin{array}{c}\text { Søreide et al. [22] } \\
\text { High-Temperature \& High-Pressure } \\
\text { Sulfuric Acid Leach Process }\end{array}$} \\
\hline & $\begin{array}{l}\text { Mining } \\
\text { (wet) }\end{array}$ & $\begin{array}{l}\text { Trans. } \\
\text { (dry) }\end{array}$ & $\begin{array}{l}\text { Process. } \\
\text { (dry) }\end{array}$ & $\begin{array}{l}\text { Mining } \\
\text { (wet) }\end{array}$ & $\begin{array}{l}\text { Trans. } \\
\text { (dry) }\end{array}$ & $\begin{array}{l}\text { Process. } \\
\text { (dry) }\end{array}$ & $\begin{array}{l}\text { Mining } \\
\text { (wet) }\end{array}$ & $\begin{array}{l}\text { Trans. } \\
\text { (dry) }\end{array}$ & $\begin{array}{l}\text { Process. } \\
\text { (dry) }\end{array}$ & $\begin{array}{l}\text { Mining } \\
\text { (wet) }\end{array}$ & $\begin{array}{l}\text { Trans. } \\
\text { (dry) }\end{array}$ & $\begin{array}{c}\text { Process. } \\
\text { (dry) }\end{array}$ \\
\hline Production $(t / y)$ & $2.3 \mathrm{M}$ & $1.5 \mathrm{M}$ & $1.5 \mathrm{M}$ & $4.2 \mathrm{M}$ & $3.0 \mathrm{M}$ & $3.0 \mathrm{M}$ & $2.3 \mathrm{M}$ & $1.5 \mathrm{M}$ & $1.5 \mathrm{M}$ & $1.1 \mathrm{M}$ & $0.7 \mathrm{M}$ & $0.7 \mathrm{M}$ \\
\hline Operation days & $300 \mathrm{~d} / \mathrm{y}$ & $300 \mathrm{~d} / \mathrm{y}$ & $330 \mathrm{~d} / \mathrm{y}$ & $300 \mathrm{~d} / \mathrm{y}$ & $300 \mathrm{~d} / \mathrm{y}$ & $330 \mathrm{~d} / \mathrm{y}$ & $250 \mathrm{~d} / \mathrm{y}$ & & & & & \\
\hline Capital expenditure (CAPEX) & $\$ 180 \mathrm{M}$ & $\$ 176 \mathrm{M}$ & $\$ 513 \mathrm{M}$ & $\$ 590 \mathrm{M}$ & $\$ 310 \mathrm{M}$ & $\$ 727 \mathrm{M}$ & $\$ 282 \mathrm{M}$ & $\$ 188 \mathrm{M}$ & $\$ 470 \mathrm{M}$ & $\$ 127 \mathrm{M}$ & $\$ 93 \mathrm{M}$ & $\$ 271 \mathrm{M}$ \\
\hline Equity/Loan & $100 / 0$ & & & $100 / 0$ & & & $50 / 50$ & & & $30 / 70$ & & \\
\hline $\begin{array}{c}\text { Operating expenditure (OPEX) } \\
\text { Loan interest } \\
\text { Survey cost }\end{array}$ & $\begin{array}{l}\$ 45 \mathrm{M} \\
0 \% \\
\$ 6 \mathrm{M}\end{array}$ & $\$ 25 \mathrm{M}$ & $\$ 165 \mathrm{M}$ & $\begin{array}{c}\$ 77 \mathrm{M} \\
0 \% \\
\$ 3 \mathrm{M}\end{array}$ & $\$ 37 \mathrm{M}$ & $\$ 111 \mathrm{M}$ & $\$ 48 \mathrm{M}$ & $\$ 36 \mathrm{M}$ & $\$ 156 \mathrm{M}$ & $\begin{array}{c}\$ 21.8 \mathrm{M} \\
8 \% \\
\$ 1.9 \mathrm{M}\end{array}$ & $\$ 13.5 \mathrm{M}$ & $\$ 22.9 \mathrm{M}$ \\
\hline OPEX ratio & $19 \%$ & $11 \%$ & $70 \%$ & $34 \%$ & $16 \%$ & $50 \%$ & $20 \%$ & $15 \%$ & $65 \%$ & $38 \%$ & $23 \%$ & $39 \%$ \\
\hline $\begin{array}{l}\text { Metal } \\
\mathrm{Co} \\
\mathrm{Ni} \\
\mathrm{Cu} \\
\mathrm{Mn}\end{array}$ & $\begin{array}{c}\text { Price } \\
\$ 5.5 / \mathrm{lb} \\
\$ 3.75 / \mathrm{lb} \\
\$ 1.25 / \mathrm{lb} \\
\$ 0.4 / \mathrm{lb} \\
\end{array}$ & $\begin{array}{c}\text { Recovery } \\
85 \% \\
95 \% \\
95 \% \\
93 \% \\
\end{array}$ & $\begin{array}{c}\text { Product } \\
3375 \mathrm{t} / \mathrm{y} \\
18,525 \mathrm{t} / \mathrm{y} \\
15,675 \mathrm{t} / \mathrm{y} \\
404,550 \mathrm{t} / \mathrm{y} \\
\end{array}$ & $\begin{array}{c}\text { Price } \\
\$ 8.53 / \mathrm{lb} \\
\$ 3.62 / \mathrm{lb} \\
\$ 1.17 / \mathrm{lb}\end{array}$ & $\begin{array}{c}\text { Recovery } \\
65 \% \\
92 \% \\
92 \%\end{array}$ & $\begin{array}{c}\text { Product } \\
5070 \mathrm{t} / \mathrm{y} \\
36,708 \mathrm{t} / \mathrm{y} \\
28,704 \mathrm{t} / \mathrm{y}\end{array}$ & $\begin{array}{c}\text { Price } \\
\$ 6.8 / \mathrm{lb} \\
\$ 3.6 / \mathrm{lb} \\
\$ 0.95 / \mathrm{lb} \\
\$ 0.3 / \mathrm{lb} \\
\end{array}$ & $\begin{array}{c}\text { Recovery } \\
85 \% \\
95 \% \\
95 \% \\
93 \% \\
\end{array}$ & $\begin{array}{c}\text { Product } \\
3525 \mathrm{t} / \mathrm{y} \\
19,730 \mathrm{t} / \mathrm{y} \\
17,810 \mathrm{t} / \mathrm{y} \\
382,500 \mathrm{t} / \mathrm{y} \\
\end{array}$ & $\begin{array}{c}\text { Price } \\
\$ 20 / \mathrm{lb} \\
\$ 3.33 / \mathrm{lb} \\
\$ 1 / \mathrm{lb}\end{array}$ & $\begin{array}{c}\text { Recovery } \\
83 \% \\
98 \% \\
97 \%\end{array}$ & $\begin{array}{l}\text { Product } \\
2652 \mathrm{t} / \mathrm{y} \\
2548 \mathrm{t} / \mathrm{y} \\
1890 \mathrm{t} / \mathrm{y}\end{array}$ \\
\hline $\begin{array}{l}\text { Taxes } \\
\text { NPV } \\
\text { IRR }\end{array}$ & $\begin{array}{l}46 \% \\
6.4 \%\end{array}$ & & & $\begin{array}{c}\text { Total } 29 \% \\
7.4 \%\end{array}$ & & & $12 \%$ & & & $\begin{array}{c}10 \% \\
-81 \mathrm{M} \\
9.6 \%\end{array}$ & & \\
\hline
\end{tabular}


The first stage of research and development (R\&D) activities for FN mining was conducted by the international consortium in the 1960s and 1970s [24-26]. Though some of the consortium's technological results were reported [27-32], most of the technically important data and results remain secret. The second stage was followed by several national projects [21,33-37]. Many publications were available from the national projects and other studies regarding seafloor FN miner design [38-42], the hydraulic lifting characteristics of FN in a pipeline [43-47], and the hydro-dynamics of the pipeline [48-52]. Among the national projects, ones conducted by China, India, Korea, and InterOceanMetals are still active.

Some important results and reviews of FN metallurgical processing have also been reported [53-59]. Most of the proposed processing methods were examined in Kojima [56], and the smelting and chlorine leaching method (SCL) was concluded to have an advantage in the study, though its cost was relatively higher than that of some hydro-metallurgical methods because of its waste-free characteristics.

The specifications of mining $5000 \mathrm{t} / \mathrm{d}$ in dry conditions, the transportation and the metallurgical processing systems, and the capital and operation expenditures (CAPEX and OPEX) of FN production were discussed in the ISA workshop in Chennai, India, in 2008. About 50 specialists in FN mining technologies, metallurgical processing, economy, and international law of the sea attended. The ISA controls all mineral resources-related activities in the international seabed area by law. Mining and metallurgical processing methods and cost analysis models were presented at first, then three working groups related to the mining technology, the metallurgical processing, and the economic model were created and the working groups reviewed the past published R\&D results and models. At the end of the workshop, CAPEX, OPEX, and methods for mining, transportation, metallurgical processing, and model selection in the working groups were reported. Four mining methods with different collectors and risers and one processing method with hydrometallurgy were included in the report. The four mining methods involved using (a) a passive collector, (b) a tracked collector, (c) a Chinese collector with a steel riser pipe, and (d) Indian small tracked collectors with flexible risers. Applying the results of the workshop, the results of the economic feasibility analyses, including manganese recovery conducted after the workshop, were distributed to the attendees of the workshop [60]. Only the summary was open to the public [61]. Though updated distribution models of the CCZ have been presented by the ISA in the last ten years $[62,63]$, no effective economic feasibility study has been undertaken.

\section{Previous Economic Evaluation of REE-Rich Mud Mining}

In the previous study [8], a production scale of $4000 \mathrm{t} / \mathrm{d}$ for REE-rich mud in dry conditions was assumed. Among the specifications for the mining, the transportation, the metallurgical processing systems, and CAPEX and OPEX for $5000 \mathrm{t} / \mathrm{d}$ of FN production in dry conditions in the ISA workshop report [60], the same tracked collector and lift subsystems for FN were assumed as the ones for REE-rich mud. The CAPEX and OPEX for a larger production scale of FN than the ones for REE-rich mud were thought to cover some additional expenditures for REE-rich mud sub-systems. On the other hand, the mining vessel and many of the onboard facilities were newly examined and roughly designed in the study. Additionally, an acid leach and solvent separation process similar to that of Abe et al. [3] was assumed in the rare-earth element recovery. The similarities and differences between FN and REE-rich mud mining assumed in the study are summarized in Table 2. Though the mud excavator is different in terms of the nodule collector and the depth is more than that in the ISA model, all the CAPEX and OPEX of the system components such as excavator, riser, and pump and some of the onboard facilities were assumed to be the same as in the ISA model for the tracked collector and lift sub-systems. If the water content of REE-rich mud is assumed to be $66.7 \%$, roughly estimated value from photos the core samples, the bulk density becomes about $1.5 \mathrm{~g} / \mathrm{cm}^{3}$. Because of the high cohesiveness of REE-rich mud, the spatial concentration in the riser is kept similar to that 
in the ISA model. Thus, the daily production of REE-rich mud in the same mining system with the ISA model becomes about $4000 \mathrm{t} / \mathrm{d}$ in dry conditions under a $40,000 \mathrm{~m}^{3}$ daily volume of mud and water mixture lifted. The volumetric concentration is $6.67 \%$. Because the mining site is in an open ocean area and close to equator, the total operation days per year were assumed as 250 days from the data used for the Japanese FN collector test near Minamitorishima Island [35]. The thickness of the excavated sediment layer was assumed to be $5 \mathrm{~m}$ from the seafloor and the average rare-earth element content was assumed to be about 2000 ppm.

Table 2. Similarities and differences between rare-earth element-rich mud (REE-rich mud) and FN mining.

\begin{tabular}{ccc}
\hline Item & REE-Rich Mud & FN \\
\hline Water depth & $5600-5800 \mathrm{~m}$ & about $5000 \mathrm{~m}$ \\
Seafloor excavation & Hydraulic cut and suction & Hydraulic suction \\
Lift & Pump hydraulic in riser & Pump hydraulic in riser \\
Dewatering & Settlement and dry-up & Separation and dry-up \\
Transport & $2000 \mathrm{~km}$ by cargo carrier to Japan's main land & $2000-5000$ km by cargo carrier to North America \\
Processing & Acid leach and solvent separation & Hydro-metallurgy \\
\hline
\end{tabular}

The mining vessel herself and many of the onboard facilities were assumed to be different from those of the ISA model. The most important point in the design of the onboard facilities is how to concentrate the mud and water mixture. The easiest and cheapest method for concentration is gravity settling in a tank. Because REE-rich mud is classified into silty clay from a water depth of 5600 to $5800 \mathrm{~m}$, it is difficult to achieve gravity settling. However, the cohesion of clayey particles accelerates the settling process [64]. Therefore, the use of a four-tank concentration and dewatering system for 4 days was proposed and assumed. One of the tanks was used for receiving the mud and water mixture on the first day. Then, on the second day it was used for gravity settling for 1 day. The supernatant water was discharged from the tank into the middle water column at a depth of $500 \mathrm{~m}$ because no chemical treatment was applied. The water content of the settled REE-rich mud at this stage became about $90 \%$ and the specific density is $1.15 \mathrm{~g} / \mathrm{cm}^{3}$. The dry-up dewatering operation was separated into two stages. At first, a moderate temperature of 60-80 degrees in Celsius $\left({ }^{\circ} \mathrm{C}\right)$ was applied to the settled mud for 1 day, then a temperature of $110^{\circ} \mathrm{C}$ was used for 1 day in the same tank. The 1-day products stayed in the same tank. It was necessary to install water discharge and dry-up facilities in all the four tanks. Because of these installations, however, mud transfer among the tanks was not necessary. At the end of the concentration and dewatering after 4 days, the dried mud cakes were transferred and stored until they had to be loaded into a transportation vessel. The size of the mining vessel had to be large because of the four tanks, storage area, and other onboard facilities necessary.

Three economic measures calculated in the previous study were the net present value (NPV), the internal rate of return (IRR), and the payback period (PP). Though the rareearth element prices given in the study were considered to be very expensive ones in 2012 and the waste disposal cost was not included, the results presented were minus $\$ 549 \mathrm{M}$ in NPV, minus $2.73 \%$ in IRR, and N/A in PP. None of these are good values in terms of economy. The main reasons for these values were the use of the large mining vessel, the lower concentration of slurry in the riser, and the lower income from rare-earth element sales.

\section{Mining Model: Combined Mining of REE-Rich Mud and FN by Pulp-Lifting}

In 2016, a vast FN area of co-distribution with REE-rich mud was found by JAMSTEC near Minamitorishima Island in the Japanese EEZ. The location and nodule distribution aspects were introduced [65]. The area size was expected to be $44,000 \mathrm{~km}^{2}$ at the time, and updated information for nodule distribution in this area has been reported [66]. The metal contents of FN were similar to those of the cobalt-rich ferromanganese crusts on the Pacific 
seamounts [67]. The same type of co-distribution area-FN with REE-rich mud-has been found beyond the Japanese EEZ around Minamitorishima Island, and China was authorized a third FN contract in the co-distribution areas next to the Japanese EEZ from ISA in 2019 [68].

Because of the co-distribution, a unique lift method is applicable for the combined mining of REE-rich mud and FN. The method is called pulp-lifting. It was investigated in a French FN R\&D program in the 1980s [43]. A non-Newtonian solid-water mixture with a high solid volumetric concentration of 55 60\% was created by mixing crushed FN, deepsea sediments, and water. Then, the mixture was circulated in a $15 \mathrm{~m}$ vertical experimental pipeline by a piston pump. Because of the drastic reduction in frictional resistance between the pipe wall and the high-concentration pulp, it was clarified that the pipe diameter would be about half of the one needed for a same-nodule mass transportation under a normal solid-liquid slurry. The pump power necessary was found to be lower than one needed for the same mass transportation one under solid-liquid slurry conditions. Pulp-lifting has never been used in any deep-sea mining programs, but the method is popularly applied for coal-water mixtures (CWMs) in many coal electricity power stations. CWM created by powder coal and water with a mass concentration of about $70 \%$ is supplied to a boiler through a pipeline [69].

In the mining model of REE-rich mud and FN proposed in this study, the following assumptions were selected as basic conditions from the reviewed FN mining technologies, including feasibility studies, metallurgy, and other factors:

- Production rate of $6000 \mathrm{t} / \mathrm{d}$ in dry conditions in REE-rich mud and $3000 \mathrm{t} / \mathrm{d}$ in dry conditions in FN;

- Hydraulic cut and suction for REE-rich mud excavation;

- Hydraulic suction for FN collection then crushing;

- Mixing and pulp-making then feeding to a piston pump;

- Pumping up through a riser;

- Solid volumetric concentration of $55 \%$ and seawater concentration of $45 \%$ in pulp;

- Water depth of $5800 \mathrm{~m}$;

- $\quad$ Drying lifted pulp then transferring it to carrier vessels;

- Transportation distance of $2000 \mathrm{~km}$ from Minamitorishima Island EEZ to the leaching and processing location in Japan's mainland;

- Separation of REE-rich mud and crushed FN;

- Leaching by $\mathrm{HCl}$ and solvent extraction with recovery ratios of $24 \%$ for Ce and $92 \%$ for other rare-earth elements in REE-rich mud [3];

- $\quad$ Brick making by adding cement powder to the leached mud after neutralization and desalting then providing it for construction material free of charge;

- Processing by SCL with recovery ratios of $80 \%$ for Mn and $94 \%$ for the other three metals in FN [56];

- $\quad$ Processed slag sales as concrete aggregate in $100 \mathrm{\$} / \mathrm{t}$;

- Calculating the CAPEX and OPEX of the mining model except for the brick-making and processing using an equation based on ones in the previous study [8]:

$$
C_{\mathrm{A}}=C_{\mathrm{B}}\left(\frac{\mathrm{a}_{\mathrm{A}}}{\mathrm{a}_{\mathrm{B}}}\right)^{n}
$$

where $C_{\mathrm{A}}=$ the value in this study; $C_{\mathrm{B}}=$ the value in the previous study; $\mathrm{a}_{\mathrm{A}}=$ the total mass in this study; $\mathrm{a}_{\mathrm{B}}=$ the total mass in the previous study; $n=0.6$ scale factor [70].

- $\quad$ Calculating the CAPEX and OPEX of the brick-making on the basis of Tsuji et al. [71];

- Calculating the CAPEX and OPEX of the processing using Equation (1) on the basis of Kojima [56] and Park et al. [72].

One of the most important assumptions is the production rate of $6000 \mathrm{t} / \mathrm{d}$ in dry conditions in REE-rich mud. This was calculated from Japan's domestic rare-earth element consumptions and the rare-earth element contents of the REE-rich mud recovered. The 
production rate of $3000 \mathrm{t} / \mathrm{d}$ in dry conditions in FN was selected as half of REE-rich mud. Japan's domestic consumptions of the four metals are quite a lot larger than the masses recovered. Because higher concentrations of REE-rich mud and crushed FN and lower amounts of seawater from the pulp-lifting come up to the mining vessel, everything underwater and the onboard facilities including the vessel herself are smaller than those used the previous studies $[3,8,60]$. The direct drying of the lifted pulp is also induced from the higher concentrations. The separation of water from the pulp is difficult but the drying process is easy. One more important point is the selection of the metallurgical processing method. The SCL is a waste-free method and the best choice for Japan's social and geographical situation. The slag is reused after smelting for aggregate and the sulfur liquid after the leaching is refreshed and reused for leaching. The CAPEX and the OPEX of the mining system are less expensive, as shown in Table 3. In the recovery of REE-rich mud on the seafloor, it is difficult to remove the overlaid sediment layer with smaller rare-earth element contents. An averaged rare-earth element content from the seafloor surface to the target depth of about 1000 ppm, the same as in Abe et al. [3] shown in Table 4, is assumed in the mining model. For example, the average top $5 \mathrm{~m}$ of the sediment column becomes $1000 \mathrm{ppm}$ in the case of $0 \mathrm{ppm}$ from the seafloor surface through to $4 \mathrm{~m}$ and $5000 \mathrm{ppm}$ from 4 through to $5 \mathrm{~m}$. The metal contents of FN presented by JAMSTEC [65] and shown in Table 5 are assumed in the mining model. They are cobalt-rich, copper-poor, and nickel-poor, similar to the cobalt-rich ferromanganese crusts on the Pacific seamounts and different from the FN in the CCFZ.

Table 3. Estimated capital and operating expenditures (CAPEX and OPEX) under basic conditions.

\begin{tabular}{ccc}
\hline & CAPEX (\$M) & OPEX (\$M) \\
\hline Mining & 179.7 & 80.7 \\
Transportation & 223.8 & 33.7 \\
Leaching (REE-mud) & 198.3 & 261.9 \\
Brock making & 155.6 & 226.0 \\
Processing (FN) & 863.6 & 110.8 \\
Total & 1621.0 & 713.1 \\
\hline
\end{tabular}

REE-mud: rare-earth element-rich mud; FN: ferromanganese nodule.

Table 4. Element contents in REE-rich mud assumed from Abe et al. [3].

\begin{tabular}{cc}
\hline Element & Content $(\mathbf{p p m})$ \\
\hline $\mathrm{Ce}$ & 177.9 \\
$\mathrm{La}$ & 154.0 \\
$\mathrm{Pr}$ & 46.2 \\
$\mathrm{Nd}$ & 192.6 \\
$\mathrm{Sm}$ & 44.9 \\
$\mathrm{Eu}$ & 11.1 \\
$\mathrm{Gd}$ & 49.0 \\
$\mathrm{~Tb}$ & 7.3 \\
$\mathrm{Dy}$ & 45.4 \\
$\mathrm{Y}$ & 277.2 \\
\hline
\end{tabular}

Table 5. Metal contents in FN assumed from the Japan Agency for Marine-Earth Science and Technology (JAMSTEC) [65].

\begin{tabular}{cc}
\hline Metal & Content (\%) \\
\hline $\mathrm{Ni}$ & 0.4 \\
$\mathrm{Cu}$ & 0.2 \\
$\mathrm{Co}$ & 0.5 \\
$\mathrm{Mn}$ & 20.0 \\
\hline
\end{tabular}




\section{Economic Feasibility of the Combined Mining of REE-Rich Mud and FN by Pulp-Lifting}

\subsection{Results of Basic Condition}

Data on prices of rare-earth elements are available through paying member sites [73,74]. In this study, based on the 5-year average prices of rare-earth elements in the period 2013-2017 [75] (to exclude the higher ones in 2012), the 10-year average prices of the four metals in the period 2008-2017 [75], the contents in Tables 4 and 5, and their recovery ratios assumed in the mining model, the revenues of the mining model under the basic conditions are calculated as shown in Table 6. It is obvious that the revenues from FN are 4.7 times more than the ones from REE-rich mud under the basic conditions of the combined mining model. In the economic evaluation, the first 3 years are assumed to be devoted to construction with no income, while the fourth year is assumed to be used for test operations with $50 \%$ income. Then, the next 16 years, from the 5 th year to the 20 th year, are assumed to be used for full mining, with $100 \%$ income. The total yearly income is calculated as about $\$ 780 \mathrm{M}$, because the revenues listed in Table 6 and about $\$ 50 \mathrm{M}$ from the slag sales are the total. The same three economic measures-NPV, IRR, and PP-are calculated as shown in Table 7. The results show a slight negative economy.

Table 6. Assumed prices and estimated revenues with their production under the basic conditions.

\begin{tabular}{ccc}
\hline Element and Metal & Price $\mathbf{( \$ / t )}$ & Yearly Revenue $\mathbf{( \$ M )}$ \\
\hline $\mathrm{Ce}$ & 15,000 & 1.2 \\
$\mathrm{La}$ & 15,000 & 3.8 \\
$\mathrm{Pr}$ & 125,833 & 9.6 \\
$\mathrm{Nd}$ & 83,333 & 26.6 \\
$\mathrm{Sm}$ & 35,000 & 2.6 \\
$\mathrm{Eu}$ & $1,500,000$ & 27.6 \\
$\mathrm{Gd}$ & 100,000 & 8.1 \\
$\mathrm{~Tb}$ & $1,033,333$ & 12.5 \\
$\mathrm{Dy}$ & 508,333 & 38.2 \\
$\mathrm{Y}$ & 56,666 & 26.0 \\
$\mathrm{Ni}$ & 16,121 & 51.8 \\
$\mathrm{Cu}$ & 6678 & 11.3 \\
$\mathrm{Co}$ & 34,698 & 155.6 \\
$\mathrm{Mn}$ & 2463 & 354.7 \\
$\mathrm{Total}$ & & 729.6 \\
\hline
\end{tabular}

Table 7. Result of the economic evaluation under basic conditions.

\begin{tabular}{ccc}
\hline NPV (\$M) & IRR (\%) & PP (year) \\
\hline-526.7 & 3.66 & 15 \\
\hline
\end{tabular}

\subsection{Sensitivity Analyses by FN Production Rate}

Because the revenues from FN shown in Table 7 have larger effects on economy, sensitivity analyses using the FN production rate are examined. In the analyses, the production of REE-rich mud is fixed as $6000 \mathrm{t} / \mathrm{d}$ and the one for FN is increased from 3000 to $7000 \mathrm{t} / \mathrm{d}$. In each of the analyses, CAPEX, OPEX, and the income are recalculated. The results of the NPV are summarized in Figure 1. About $4000 \mathrm{t} / \mathrm{d}$ is found as the point of $\mathrm{NPV}=0$. 


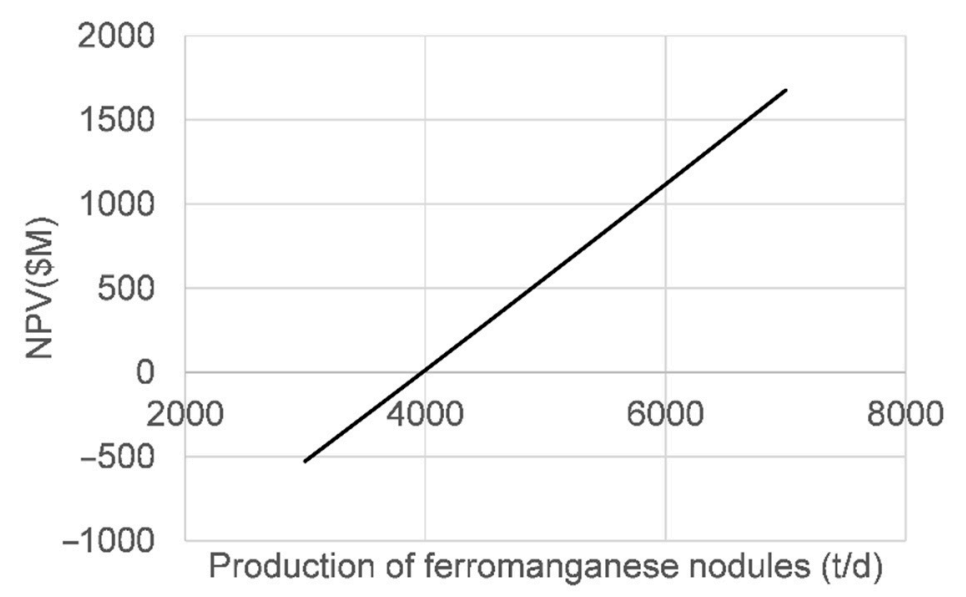

Figure 1. Sensitivity analyses of net present value (NPV) using FN production rates.

\section{Expected Geotechnical Characteristics of REE-Rich Mud}

Because the water depth, $5600-5800 \mathrm{~m}$, is deeper than the carbonate compensation depth (CCD), REE-rich mud is composed of siliceous particles and classified into pelagic clay. No geotechnical data such as water content and cohesiveness are available to examine technical problems for REE-rich mud excavation on the seafloor. Though some data are available on deep-sea siliceous sediments [76,77], the technical problems expected for the excavation were examined based on the little data available. Example geotechnical properties of siliceous deep-sea sediments in shallow layers are shown in Figure 2 [76] and properties from shallow to deep layers are shown in Figure 3 [77]. Using recovered box-core samples, $50 \mathrm{~cm}$ square and $30-40 \mathrm{~cm}$ in height, the vane shear strength, sensitivity, water content, and cone penetration resistance were measured in the core column, as shown in Figure 2 [76]. In the vane shear strength and the sensitivity, the relationship is defined by Equation (2) [78]. In Figures 2 and 3, the water content was calculated by Equation (3). The relationships among the geotechnical strength characteristics of clayey sediments are generally given by Equation (4) [79]. Using a recovered gravity-core sample that was $11 \mathrm{~cm}$ in diameter and $261 \mathrm{~cm}$ in height, measurements of some geotechnical factors were conducted. From these factors, the solid density, bulk density, and water content were calculated, as shown in Figure 3 [77]. From the obtained results shown in Figure 3, the highly cohesive and clayey nature of the gravity-core sample was recognized.

$$
S_{t}=S_{v o} / S_{v r}
$$

where $S_{t}=$ sensitivity, $S_{v o}=$ original undisturbed vane shear strength, $S_{v r}=$ remolded vane shear strength.

$$
w=\left(W_{W}-W_{O}\right) / W_{O} \times 100
$$

where $w=$ water content, $W_{w}=$ water-saturated weight in air, $W_{o}=$ dried weight in air.

$$
q_{u}=0.2 \times q_{c}=2 \times S_{v o}
$$

where $q_{u}=$ undisturbed uniaxial strength, $q_{c}=$ cone penetration resistance. 
83B86

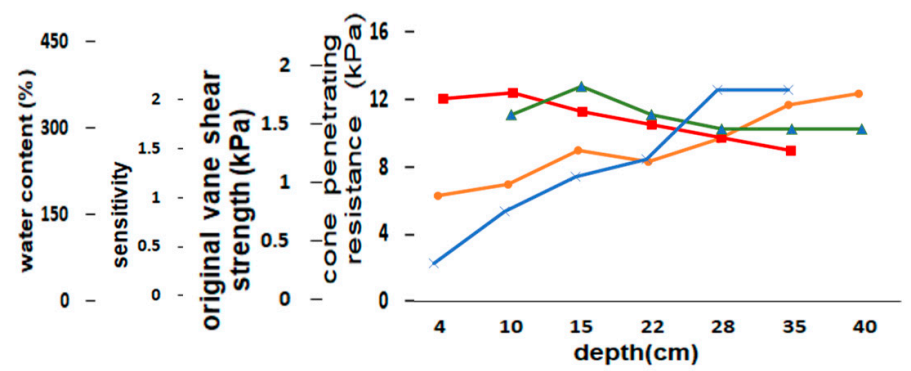

$83 \mathrm{~B} 97$

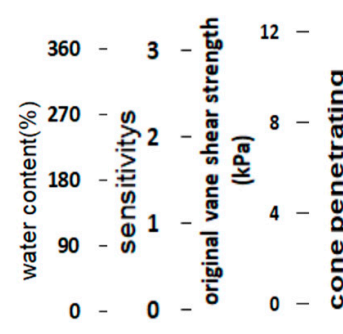

\section{B91}

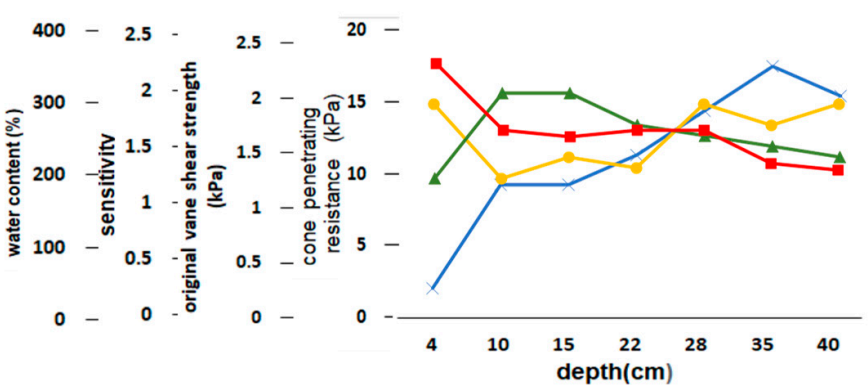

$83 \mathrm{~B} 100$

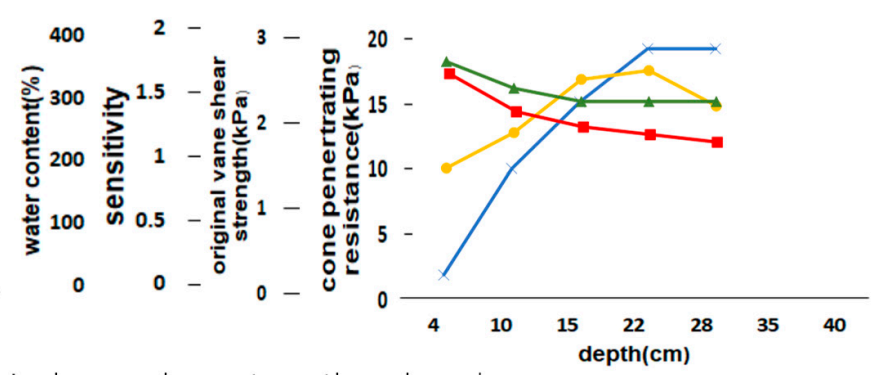

original vane shear strength
Xater content on board
X consitivity on board
coresistance on board

Figure 2. Example geotechnical properties of siliceous deep-sea sediments in shallow layers at Penrhyn Basin, South Pacific, about $5200 \mathrm{~m}$ deep [76].

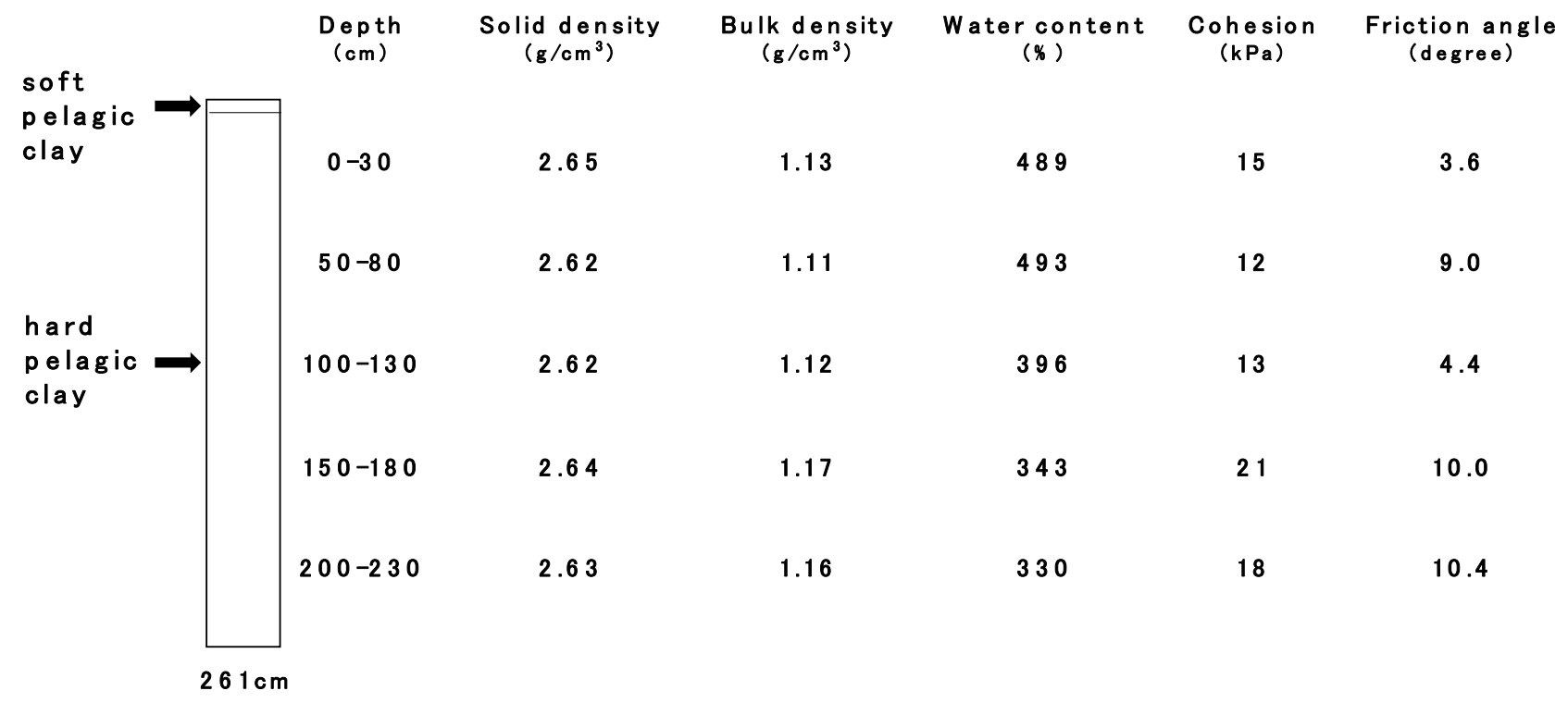

Figure 3. Example geotechnical properties of siliceous deep-sea sediments from shallow to deep layers in the Japanese FN contract area in the Clarion-Clipperton Fracture Zone (CCZ), North Pacific, about $5200 \mathrm{~m}$ deep [77]. 


\section{Technical Considerations}

The solid density of $3.25 \mathrm{~g} / \mathrm{cm}^{3}$ and the porosity of $55 \%$ were reported for FN [80]. From these values, the volumetric concentration of about $45 \%$ for FN was calculated. From the water contents, 200 350\% in Figure 2 and 330 493\% in Figure 3, the volumetric concentration of 7 16\% is expected for REE-rich mud. The value of $45 \%$ for FN is not bad, but the value of 7 16\% for REE-rich mud is quite low compared with the one of $55 \sim 60 \%$ in the French pulp-lifting experiment [43]. To create a good pulp condition, the question of how to reduce seawater in REE-rich mud on the seafloor is considered to be of primary importance. The high cohesiveness of $12 \sim 21 \mathrm{kPa}$ in Figure 3 is the secondary problem, but the sensitivity of about 3 in Figure 2 looks to be helpful to reduce the cohesiveness by remolding REE-rich mud during the excavation. The question of how to crush FN and make smaller particles on the seafloor is the third problem. Meanwhile, how to mix REE-rich mud and the crushed FN particles is the fourth problem and how to feed the mixture to a piston pump is the fifth. A good water content of REE-rich mud and a good size distribution of crushed FN for pulp-lifting must be experimentally clarified at first.

The next important is the service lifetime of the riser pipe. From the viewpoint of economy, usually the usage of a steel pipe is assumed in deep-sea mining models [2-4,8,19-21,60,72] and in this study, except in the mechanical lift model [22]. The other technological studies introduced as references in this study are related to the lift conditions in the steel pipe and the pipe dynamics of the steel pipe, except for the studies on metallurgical processing. However, the relatively short time of 2-5 years was reported in the case of the $1700 \mathrm{~m}$ water depth and several hundred tons in weight, including a submerged pump under a maximum wave height of $6 \mathrm{~m}$ for massive seafloor sulfide mining in Papua New Guinea [81]. In the case of deeper and rough wave conditions for the combined mining of REE-rich mud and FN, a shorter service lifetime is expected. Depending on the lifetime, it should be concluded that there would be greater OPEX for the steel riser pipe. The clarification of this problem is necessary.

Some other technical efforts such as clarifying the brick-making process by adding cement powder to the waste mud and checking the engineering properties of the processed slag as concrete aggregate are also important, because these are key points in their reuse.

After these technical clarifications, a realistic economic feasibility analysis will be conducted. We note that although detailed and useful geological data of REE-rich mud have already been published [82-85], the geotechnical data corresponding to geological variations are not available currently.

\section{Mining Area Management Plan}

The mining area sizes necessary for the combined mining of REE-rich mud and FN are different. If the average FN population in the co-distribution area is the same as the one in CCFZ- $10 \mathrm{~kg} / \mathrm{m}^{2}$ in wet conditions - the population in dry conditions becomes $7.2 \mathrm{~kg} / \mathrm{m}^{2}$ for the solid density and porosity of FN. Under the FN population, $417,000 \mathrm{~m}^{2}$ per day must be covered for an FN production of $3000 \mathrm{t} / \mathrm{d}$. In case of an REE-rich mud production of $6000 \mathrm{t} / \mathrm{d}$ under the mining model and geotechnical characteristics detailed in this study, $4000 \mathrm{~m}^{2}$ per day must be excavated up to $5 \mathrm{~m}$ deep. The area size for REE-rich mud is only about $1 \%$ of that for FN. To minimize the horizontal transportation distance, the mining site for REE-rich mud should be placed at the center of the one for FN. The daily mining area management is expected to be similar to that in Figure 4. The area size of the co-distribution of REE-rich mud and FN increased from the first press release value of $44,000 \mathrm{~km}^{2}$ [65] to the updated value of $70,500 \mathrm{~km}^{2}$ [66]. From the area size necessary for daily FN mining, about 560 years (under 300 days of operation per year) is the expected lifetime of the combined mining under the basic conditions in the Japanese EEZ around Minamitorishima Island. 


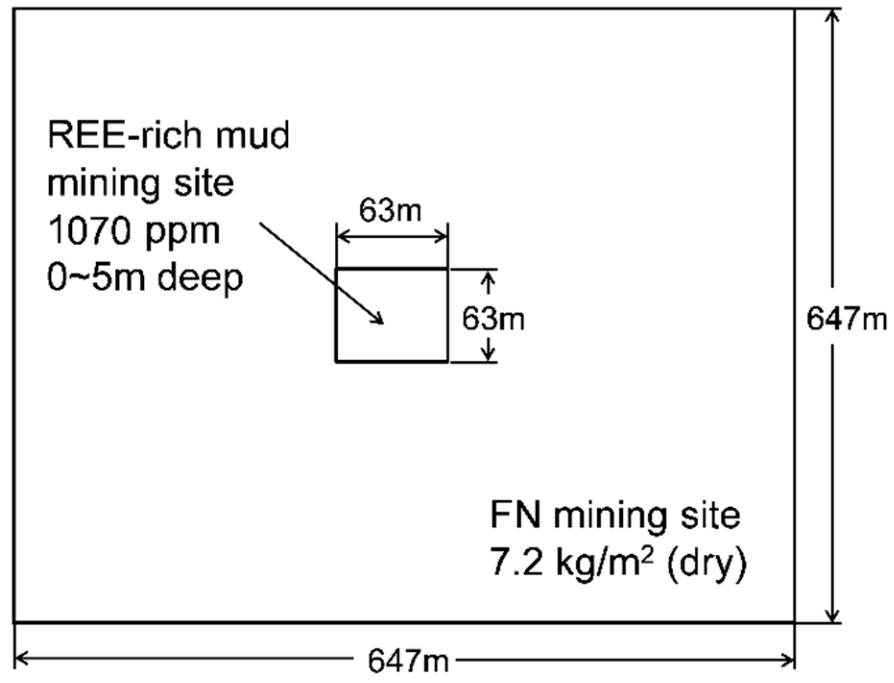

Figure 4. Daily mining area management for the combined mining of REE-rich mud and FN (not in an accurate scale).

\section{Concluding Remarks}

The area of the co-distribution of REE-rich mud and FN in the Japanese EEZ has a chance to be used for commercial mining. The following three innovative changes in the mining model have improved the economy of the mining:

- Combined mining with REE-rich mud and FN;

- Pulp-lifting;

- Reuse of waste mud and processed slag as construction materials.

The production ratio of $6000 \mathrm{t} / \mathrm{d}$ for REE-rich mud versus $3000 \mathrm{t} / \mathrm{d}$ for FN is slightly negative in economy. More FN in the pulp concentrates is necessary for a better economy. An appropriate water content of REE-rich mud and a good size distribution of crushed FN for pulp-lifting must be clarified first.

Author Contributions: Conceptualization, T.Y. and N.N.; methodology, T.Y.; software, T.Y.; validation, N.N. and R.A.; investigation, T.Y.; resources, T.S. and H.K.; writing —original draft preparation, T.Y.; writing — review and editing, T.S. and H.K.; supervision, R.A.; project administration, N.N. All authors have read and agreed to the published version of the manuscript.

Funding: This research received no external funding.

Institutional Review Board Statement: Not applicable.

Informed Consent Statement: Not applicable.

Data Availability Statement: Not applicable.

Acknowledgments: The data curation of the study was conducted by Kazuyuki Hayashi when he wrote a bachelor thesis related to the subject.

Conflicts of Interest: The authors declare no conflict of interest.

\section{References}

1. Kato, Y.; Fujinaga, K.; Nakamura, K.; Takaya, Y.; Kitamura, K.; Ohta, J.; Toda, R.; Nakashima, T.; Iwamori, H. Deep-sea mud in the Pacific Ocean as a potential resource for rare-earth elements. Nat. Geosci. 2011, 4, 535-539. [CrossRef]

2. Bashir, M.B.; Kim, S.H.; Kiosidou, E.; Wolgamot, H.; Zhang, W. A Concept for Seabed Rare Earth Mining in the Eastern South Pacific; LRET Collegium 2012 Series; University Southampton: Southampton, UK, 2012; Volume 1, p. 121.

3. Abe, K.; Watanabe, D.; Fujinaga, K.; Kato, Y.; Nakamura, T.; Yamazaki, T. Technical and Economic Feasibility Study on Rare-earth Elements and Yttrium-rich Mud. In Proceedings of the 23rd Ocean Engineering Symposium, Tokyo, Japan, 2-3 August 2012. JFOES \& JASNAOE, OES23-089 (In Japanese with English Abstract). 
4. Wolgamot, H.; Zhang, W.; Kiosidou, E.; Kim, S.H.; Bashir, M. Considerations for Seabed Rare Earth Mining in the Pacific. In Proceedings of the 32nd International Conference on Ocean, Offshore and Arctic Engineering, Nantes, France, 9-14 June 2013. OMAE2013-10844.

5. JAMSTEC Press Releases. Available online: http://www.jamstec.go.jp/e/about/press_release/20130321/ (accessed on 26 October 2020).

6. Iijima, K.; Yasukawa, K.; Fujinaga, K.; Nakamura, K.; Machida, S.; Takaya, Y.; Ohta, J.; Haraguchi, S.; Nishio, Y.; Usui, Y.; et al. Discovery of extremely REY-rich mud in the western North Pacific Ocean. Geochem. J. 2016, 50, 557-573. [CrossRef]

7. Takaya, Y.; Yasukawa, K.; Kawasaki, T.; Fujinaga, K.; Ohta, J.; Usui, Y.; Nakamura, K.; Kimura, J.-I.; Chang, Q.; Hamada, M.; et al. The tremendous potential of deepsea mud as a source of rare-earth elements. Sci. Rep. 2018, 8, 1-8. [CrossRef] [PubMed]

8. Yamazaki, T.; Yamamoto, Y.; Nakatani, N.; Arai, R. Preliminary Economic Evaluation of Deep-sea REE Mud Mining. In Proceedings of the 33rd International Conference on Ocean, Offshore and Arctic Engineering, San Francisco, CA, USA, 8-13 June 2014. OMAE2014-23141.

9. Mero, J.L. The Mineral Resources of the Sea; Oceanography Series, 1; Elsevier: Amsterdam, The Netherlands, $1965 ;$ p. 312.

10. Cronan, D.S. Underwater Minerals; Academic Press: London, UK, 1980; p. 362.

11. Craig, J.D.; Andrews, J.E. A Factor Analysis Study of Deep Sea Ferromanganese Deposits in the Equatorial North Pacific Ocean. Mar. Min. 1978, 1, 305-326.

12. Andrews, J.E.; Friedrich, G.H.W. Distribution Patterns of Manganese Nodule Deposits in the Northeast Equatorial Pacific. Mar. Min. 1979, 2, 1-43.

13. Friedrich, G.; Glasby, G.P.; Thijssen, T.; Plüger, W.L. Morphological and Geochemical Characteristics of Manganese Nodules Collected from Three Areas on an Equatorial Pacific Transect by RV Sonne. Mar. Min. 1983, 4, 167-253.

14. Von Stackelberg, U.; Beiersdorf, H. The Formation of Manganese Nodules between the Clarion Clipperton Fracture Zones Southeast of Hawaii. Mar. Geol. 1991, 98, 411-423. [CrossRef]

15. Morgan, C.L.; Nichols, J.A.; Selk, B.W.; Toth, J.R.; Wallin, C. Preliminary Analysis of Exploration Data from Pacific Deposits of Manganese Nodules. Mar. Georesour. Geotechnol. 1993, 11, 1-25. [CrossRef]

16. ISA. POLYDAT: Polymetallic nodule database. In Proceedings of the Workshop on Proposed Technologies for Mining DeepSeabed Polymetallic Nodules, International Seabed Authority, Kingston, Jamaica, 3-6 August 1999; pp. 447-456.

17. Padan, J.W. Commercial Recovery of Deep—Seabed Manganese Nodules: Twenty Years of Accomplishments. Mar. Min. 1990, 9, 87-103.

18. ISA. Plans of Work for Exploration of Government of India, IFREMER/AFERNOD, DORD, Yuzhmorgeologiya, COMRA, IOM, Republic of Korea; Report of the Secretary General No. ISBA/4/A/1/Rev.2; International Seabed Authority: Kingston, Jamaica, $1998 ;$ p. 47.

19. Andrews, B.V.; Flipse, J.E.; Brown, F.C. The Economic Viability of a Four-Metal Pioneer Deep Ocean Mining Venture; PB84-122563; US Dept. of Commerce: Washington, DC, USA, 1983; p. 201.

20. Hillman, C.T.; Gosling, B.B. Mining Deep Ocean Manganese Nodules: Description and Economic Analysis of a Potential Venture; IC 9015; US Bureau of Mines: Washington, DC, USA, 1985; p. 19.

21. Charles, C.; Herrouin, G.; Mauviel, F.; Bernard, J. Views on Future Nodule Technologies Based on IFREMER-GEMONOD Studies. Mater. Soc. 1990, 14, 299-326.

22. Søreide, F.; Lund, T.; Markussen, J.M. Deep Ocean Mining Reconsidered a Study of the Manganese Nodule Deposits in Cook Island. In Proceedings of the 4th ISOPE Ocean Mining Symposium, Szczecin, Poland, 23-27 September 2001; pp. 88-93.

23. Honkawa Data Tribune. Available online: https://honkawa2.sakura.ne.jp/5500.html (accessed on 26 December 2020). (In Japanese)

24. Welling, C.G. An advanced design deep sea mining system. In Proceedings of the 13th Offshore Technology Conference, Houston, TX, USA, 4-7 May 1981.

25. Kaufman, R.; Latimer, J.P.; Tolefson, D.C. The design and operation of a Pacific Ocean deep ocean mining test ship: R/V Deepsea Miner II. In Proceedings of the 17th Offshore Technology Conference, Houston, TX, USA, 6-9 May 1985.

26. Bath, A.R. Deep sea mining technology: Recent developments and future projects. In Proceedings of the 21st Offshore Technology Conference, Houston, TX, USA, 1-4 May 1989.

27. Heine, O.R.; Suh, S.L. An Experimental Nodule Collection Vehicle Design and Testing. In Proceedings of the 10th Offshore Technology Conference, Houston, TX, USA, 8-11 May 1978.

28. Clauss, G. Hydraulic Lifting in Deep-Sea Mining. Mar. Min. 1978, 1, 189-208.

29. Burns, J.Q.; Suh, S.L. Design and Analysis of Hydraulic Lift Systems for Deep Ocean Mining. In Proceedings of the 11th Offshore Technology Conference, Houston, TX, USA, 30 April 1979.

30. Grote, P.B.; Burns, J.Q. System Design Considerations in Deep Ocean Mining Lift System. Mar. Min. 1981, 2, $357-383$.

31. Chung, J.S.; Whitney, A.K.; Loden, W.A. Nonlinear Transient Motion of Deep Ocean Mining Pipe. J. Energy Resour. Technol. 1981, 103, 2-10. [CrossRef]

32. Kollwentz, W. Lessons Learned in the Development of Nodule Mining Technology. Mater. Soc. 1990, 14, $285-298$.

33. Kotlinski, R. InterOceanMetal Joint Organization: Achievements and Challenges. In Proceedings of the 1st ISOPE Ocean Mining Symposium, Tsukuba, Japan, 21-22 November 1995; pp. 5-7.

34. Yang, N.; Wang, M. New Era for China Manganese Nodules Mining: Summary of Last Five Years' Research Activities and Prospective. In Proceedings of the 2nd ISOPE Ocean Mining Symposium, Seoul, Korea, 24-26 November 1997; pp. 8-11. 
35. Yamada, H.; Yamazaki, T. Japan's Ocean Test of the Nodule Mining System. In Proceedings of the 8th International Offshore and Polar Engineering Conference, Montreal, QC, Canada, 24-29 May 1998; pp. 13-19.

36. Hong, S.; Kim, K.-H. Research and Development of Deep Seabed Mining Technologies for Polymetallic Nodules in Korea. In Proceedings of the Proposed Technologies for Deep Seabed Mining of Polymetallic Nodules, International Seabed Authority, Kingston, Jamaica, 3-6 August 1999; pp. 261-283.

37. Muthunayagam, A.E.; Das, S.K. Indian polymetallic nodule program. In Proceedings of the 3rd ISOPE Ocean Mining Symposium, Goa, India, 8-11 November 1999; pp. 1-5.

38. Li, L.; Zhang, J. The China's Manganese Nodules Miner. In Proceedings of the 2nd ISOPE Ocean Mining Symposium, Seoul, Korea, 24-26 November 1997; pp. 95-99.

39. Yasukawa, H.; Ikegami, K.; Minami, T. Motion Analysis of a Towed Collector for Manganese Nodule Mining in Ocean Test. In Proceedings of the 9th International Offshore and Polar Engineering Conference, Brest, France, 30 May-4 June $1999 ;$ pp. 100-107.

40. Hong, S.; Choi, J.-S.; Kim, J.-H.; Yang, C.-H. Experimental Study on Hydraulic Performance of Hybrid Pickup Device of Manganese Nodule Collector. In Proceedings of the 3rd ISOPE Ocean Mining Symposium, Goa, India, 8-11 November 1999; pp. 69-77.

41. Yamazaki, T.; Kuboki, E.; Yoshida, H. Tracing Collector Passes and Preliminary Analysis of Collector Operation. In Proceedings of the 3rd ISOPE Ocean Mining Symposium, Goa, India, 8-11 November 1999; pp. 55-62.

42. Deepak, C.R.; Shajahan, M.A.; Atmanand, M.A.; Annamalai, K.; Jeyamani, R.; Ravindran, M.; Schulte, E.; Handschuh, R.; Panthel J.; Grebe, H.; et al. Developmental Test on the Underwater Mining System Using Flexible Riser Concept. In Proceedings of the 4th ISOPE Ocean Mining Symposium, Szczecin, Poland, 23-27 September 2001; pp. 94-98.

43. Bernard, J.; Bath, A.R.; Greger, B. Analysis and comparison of nodule hydraulic transport systems. In Proceedings of the 9th Offshore Technology Conference, Houston, TX, USA, 27-30 April 1987; p. 5476.

44. Saito, T.; Usami, T.; Yamazaki, T.; Tomishima, Y.; Kiyono, F. Lifting Characteristics of Manganese Nodules by Air-Lift-Pump on 200m Vertical Test Plant. In Proceedings of the OCEANS'89, Seattle, WA, USA, 8-21 September 1989; pp. 48-53.

45. Xia, J.; Xia, L.; Zau, W.; Tang, D.; Huang, J.; Wang, S. Studies on Reasonable Hydraulic Lifting Parameters of Manganese Nodules. In Proceedings of the 2nd ISOPE Ocean Mining Symposium, Seoul, Korea, 24-26 November 1997; pp. 112-116.

46. Yoon, C.-H.; Kwon, K.-S.; Kwon, O.-K.; Kwon, S.-K.; Kim, I.-K.; Lee, D.-K.; Lee, H.-S. An Experimental Study on Lab Scale Air-Lift Pump Flowing Solid-Liquid-Air Three-Phase Mixture. In Proceedings of the 10th International Offshore and Polar Engineering Conference, Seattle, WA, USA, 27 May-2 June 2000; pp. 515-521.

47. Chung, J.S.; Lee, K.; Tischler, A.; Yarim, G. Effect of Particle Size and Concentration on Pressure Gradient in Two-Phase Vertically Upward Transport. In Proceedings of the 4th ISOPE Ocean Mining Symposium, Szczecin, Poland, 23-27 September 2001; pp. 132-138.

48. Aso, K.; Kan, K.; Doki, H.; Ohkoshi, T. The Effect of Vibration Absorbers on the Longitudinal Vibration of a Pipe String in the Deep Sea-Part 2: A Case of Mining Manganese Nodules. Int. J. Offshore Polar Eng. 1994, 4, 62-67.

49. Chung, J.S.; Cheng, B.-R.; Huttelmaier, H.P. Three-Dimensional Coupled Responses of a Vertical Deep-Ocean Pipe: Part II. Excitation at Pipe Top and External Torsion. Int. J. Offshore Polar Eng. 1994, 4, 321-339.

50. Cheng, B.-R.; Chung, J.S. Effects of Axial Dampers and Elastic Joints on 3-D Dynamic Responses of a Deep-Ocean Pipe with Torsional Coupling. Int. J. Offshore Polar Eng. 1997, 7, 36-43.

51. Ohta, T.; Morikawa, M. Bending Strength of Lifting Pipes Handling of Pipe Connection in Manganese Mining System. In Proceedings of the 2nd ISOPE Ocean Mining Symposium, Seoul, Korea, 24-26 November 1997; pp. 68-74.

52. Handschuh, R.; Grebe, H.; Panthel, J.; Schulte, E.; Wenzlawski, B.; Schwarz, W.; Atmanand, M.A.; Jeyamani, R.; Shajahan, M.; Deepak, R.; et al. Innovative Deep-Ocean Mining Concept Based on Flexible Riser and Self-propelled Mining Machine. In Proceedings of the 4th ISOPE Ocean Mining Symposium, Szczecin, Poland, 23-27 September 2001; pp. 99-107.

53. Agarwal, J.C.; Beecher, N.; Davies, D.S.; Hubred, G.L.; Kakaria, V.K.; Moslen, J.H. Comparative Economics of Recovery of Metals from Ocean Nodules. Mar. Min. 1979, 2, 119-130.

54. Hubred, G.L. Manganese Nodule Extractive Metallurgy Review 1973-1978. Mar. Min. 1980, 2, $191-212$.

55. Black, J.R.H. Metals Recovery from Manganese Nodules: A Review of Processing Schemes. In Marine Mining: A New Beginning; Humphrey, P.B., Ed.; Hawaii Department of Planning and Economic Development: Honolulu, HI, USA, $1982 ;$ pp. 93-107.

56. Kojima, K. Review of Studies on Manganese Nodules Processing. In Proceedings of the 2nd ISOPE Ocean Mining Symposium, Seoul, Korea, 24-26 November 1997; pp. 19-22.

57. Kim, D.-J.; Park, K.-H. Study on the Leaching Mechanism of Cu and Ni from Deep-sea Manganese Nodules with Hydrochloric Acid. In Proceedings of the 2nd ISOPE Ocean Mining Symposium, Seoul, Korea, 24-27 November 1997; pp. 172-176.

58. Xiang, Z.; Zequan, H.; Yujun, S.; Yongjun, M.; Shuguang, Q.; Xianbai, L. The Smelting-Rusting-Solvent Extraction Process to Recover Valuable Metals from Polymetallic Nodules. In Proceedings of the 3rd ISOPE Ocean Mining Symposium, Goa, India, 8-11 November 1999; pp. 227-231.

59. Das, R.P. India's Demonstration Metallurgical Plant to Treat Ocean Nodule. In Proceedings of the 4th ISOPE Ocean Mining Symposium, Szczecin, Poland, 23-27 September 2001; pp. 163-166.

60. ISA. Polymetallic Nodule Mining Technology: Current Status and Challenges Ahead. In Proceedings of the Executive Summary of ISA workshop, Chennai, India, 18-22 February 2008. 
61. ISA. Report on the International Seabed Authority's Workshop on Polymetallic Nodule Mining Technology: Current status and Challenges Ahead. Available online: https://www.isa.org.jm/files/documents/EN/14Sess/LTC/ISBA-14LTC-3.pdf (accessed on 26 October 2020).

62. ISA. A Geological MODEL of Polymetallic Nodule Deposits in the Clarion-Clipperton Fracture Zone; ISA Technical Study: No. 6; International Seabed Authority: Kingston, Jamaica, 2010; p. 211.

63. ISA. Polymetallic Nodules Resource Classification -Report of an International Workshop Held in 2014-, ISA Technical Study: No. 19; International Seabed Authority: Kingston, Jamaica, 2017; p. 79.

64. Yamazaki, T.; Kuboki, E.; Yoshida, H.; Suzuki, T. A Consideration on Size Distribution of Resuspended Deep-sea Sediments. In Proceedings of the 10th International Offshore and Polar Engineering Conference, Seattle, WA, USA, 27 May-2 June 2000; pp. 507-514.

65. JAMSTEC Press Releases. Available online: http://www.jamstec.go.jp/e/about/press_release/20160826/ (accessed on 26 October 2020).

66. Machida, S.; Sato, T.; Yasukawa, K.; Nakamura, K.; Iijima, K.; Nozaki, T.; Kato, Y. Visualisation method for the broad distribution of seafloor ferromanganese deposits. Mar. Georesour. Geotechnol. 2021, 39, 267-279. [CrossRef]

67. Machida, S.; Fujinaga, K.; Ishii, T.; Nakamura, K.; Hirano, N.; Kato, Y. Geology and geochemistry of ferromanganese nodules in the Japanese Exclusive Economic Zone around Minamitorishima Island. Geochem. J. 2016, 50, 539-555. [CrossRef]

68. ISA. Available online: https://www.isa.org.jm/exploration-contracts/beijing-pioneer-hi-tech-development-corporation and https:/ / www.isa.org.jm/map/beijing-pioneer-hi-tech-development-corporation (accessed on 26 October 2020).

69. Ogawa, J.; Shibata, K. Production Technology of COM and CWM. J. Fuel Soc. Jpn. 1990, 69, 828-832, (In Japanese with English Abstract). [CrossRef]

70. Japan Coal Development Technology Cooperation Center. Mine Investment Analysis, Overseas Coal Development Technical Guide; Japan Coal Development Technology Cooperation Center: Tokyo, Japan, 1993; Volume 2, p. 55. (In Japanese)

71. Tsuji, T.; Tanaka, Y.; Nakagawa, M.; Nonaka, S.; Nagao, K.; Akashi, Y.; Kiso, E.; Tasaki, T. Materials Properties and Production Technology of Artificial Stone Using the Dredged Soil. J. Jpn. Soc. Civ. Eng. Ser. B3 (Ocean Eng.) 2015, 71, I_1173-I_1178, (In Japanese with English Abstract).

72. Park, S.; Yamazaki, T.; Shimada, S.; Yamamoto, T. Development Potential Examination Method for Cobalt-rich Manganese Crusts. J. Min. Mater. Process. Inst. Jpn. 2002, 118, 641-649, (In Japanese with English Abstract).

73. SMM Information \& Technology. Available online: https://www.metal.com/ (accessed on 7 February 2021).

74. MetalPrices. Available online: https://mineralprices.com/ (accessed on 7 February 2021).

75. Dataset of World Economy. Available online: https:/ / ecodb.net/commodity/metal/ (accessed on 26 October 2020). (In Japanese).

76. Yamazaki, T.; Tsurusaki, K.; Handa, K.; Inagaki, T. Geotechnical Properties of Deep Ocean Sediment Layer. J. Min. Mater. Process. Inst. Jpn. 1995, 110, 309-315, (In Japanese with English Abstract).

77. Yamazaki, T.; Komine, T.; Kawakami, T. Geotechnical Properties of Deep-sea Sediments and the In-situ Measurement Techniques. In Proceedings of the 6th ISOPE Ocean Mining Symposium, Changsha, China, 9-13 October 2005; pp. 48-55.

78. Abuhajar, O.; El Naggar, M.H.; Newson, T. Review of Available Methods for Evaluation of Soil Sensitivity for Seismic Design. In Proceedings of the International Conference Recent Advances in Geotechnology, Earthquake Engineering and Soil Dynamics, San Diego, CA, USA, 24-29 May 2010. Paper No. 1.32b.

79. Yamashita, S.; Kawaguchi, T.; Ohshima, H. Design of handy cone penetration tester and its application. Jpn. Geotech. J. 2016, 11, 193-200, (In Japanese with English Abstract). [CrossRef]

80. Yamazaki, T.; Tomishima, Y.; Handa, K.; Saito, T. Studies on Characteristics of Friability of Manganese Nodules and on their Friability in the On-Board Facilities. Shigen; National Research Institute of Resources and Environment: Tsukuba, Japan, 1990; Volume 2, pp. 339-350, (In Japanese with English Abstract).

81. Stanton, P.; Yu, A. Interim Use of API Codes for Design of Dynamic Riser Systems for Deepsea Mining Industry. In Proceedings of the 29th International Conference on Ocean, Offshore and Arctic Engineering, Shanghai, China, 6-11 June 2010. OMAE2010-20189.

82. Ohta, J.; Ysukawa, K.; Machida, S.; Fujinaga, K.; Nakamura, K.; Takaya, Y.; Iijima, K.; Suzuki, K.; Kato, Y. Geological factors responsible for REY-rich mud in the western North Pacific Ocean: Implications from mineralogy and grain size distributions. Geochem. J. 2016, 50, 591-603. [CrossRef]

83. Yasukawa, K.; Kino, S.; Azuma, K.; Tanaka, E.; Miura, K.; Ohta, J.; Fujinaga, K.; Nakamura, K.; Kato, Y. Geochemical features of Fe-Mn micronodules in deep-sea sediments of the western North Pacific Ocean: Potential for co-product metal extraction from REY-rich mud. Ore Geol. Rev. 2020, 127, 103805. [CrossRef]

84. Tanaka, E.; Nakamura, K.; Yasukawa, K.; Miura, K.; Fujinaga, K.; Ohta, J.; Iijima, K.; Nozaki, T.; Machida, S.; Kato, Y. Chemostratigraphy of deep-sea sediments in the western North Pacific Ocean: Implications for genesis of mud highly enriched in rare-earth elements and yttrium. Ore Geol. Rev. 2020, 119, 103392. [CrossRef]

85. Tanaka, E.; Nakamura, K.; Yasukawa, K.; Miura, K.; Fujinaga, K.; Ohta, J.; Iijima, K.; Nozaki, T.; Machida, S.; Kato, Y. Chemostratigraphic Correlations of Deep-Sea Sediments in the Western North Pacific Ocean: A New Constraint on the Distribution of Mud Highly Enriched in Rare-Earth Elements. Minerals 2020, 10, 575. [CrossRef] 